Article

\title{
Levels of Soluble Endothelium Adhesion Molecules and Complications among Sickle Cell Disease Patients in Ghana
}

\author{
Charles Antwi-Boasiako ${ }^{1, *}$, Eric S. Donkor ${ }^{2}$, Fredericka Sey ${ }^{3}$, Bartholomew Dzudzor ${ }^{4}$, \\ Gifty B. Dankwah ${ }^{1}$, Kate H. Otu ${ }^{5}$, Alfred Doku ${ }^{6}$, Campbell A. Dale ${ }^{7}$ and Ivy Ekem ${ }^{8}$ \\ 1 Department of Physiology, School of Biomedical and Allied Health Sciences, University of Ghana, Accra, \\ Ghana; gdankwah@gmail.com \\ 2 Department of Medical Microbiology, School of Biomedical and Allied Health Sciences, University of Ghana, \\ Accra, Ghana; ericsdon@hotmail.com \\ 3 Sickle Cell Clinic, Korle-Bu Teaching Hospital, Accra, Ghana; fredisey@hotmail.com \\ 4 Department of Medical Biochemistry, School of Biomedical and Allied Health Sciences, University of Ghana, \\ Accra, Ghana; dzudzorb@yahoo.com \\ 5 Department of Nursing and Midwifery, Greenhills School of Health Sciences, Accra, Ghana; \\ kateboasiako@yahoo.co.uk \\ 6 Department of internal Medicine, School of Medicine and Dentistry, University of Ghana, Accra, Ghana; \\ dokukavin@gmail.com \\ 7 Department of Pediatric Hematology/Oncology, University of Michigan Hospitals, Ann Arbor, MI 48109, \\ USA; acampbell@childrensnational.org \\ 8 Department of Haematology, School of Medical Sciences, College of Health and Allied Sciences, \\ University of Cape Coast, Cape Coast, Ghana; ekem_ivy@hotmail.com \\ * Correspondence: antwiboasiako@gmail.com
}

Received: 27 February 2018; Accepted: 17 April 2018; Published: 21 April 2018

\begin{abstract}
Background: Soluble adhesion molecules are involved in the gathering and joining of inflammatory cells to vascular endothelium. Therefore, they serve as potential markers of endothelial dysfunction in vascular diseases including sickle cell disease (SCD). In Ghana, there are scarcely any report on the levels of adhesion molecules among SCD patients. The current study aimed to determine plasma levels of ICAM-1, VCAM-1 and E-Selectin as markers of endothelial dysfunction in SCD patients in steady state, complications and controls. Methodology: This was a cross-sectional study involving $60 \mathrm{HbAA}$ controls, $46 \mathrm{HbSS}$ steady state, $57 \mathrm{HbSS}$ VOC, $18 \mathrm{HbSC}$ VOC, $21 \mathrm{HbSS}$ with leg ulcer and $11 \mathrm{HbSS}$ with priapism. Blood samples were collected from all the study subjects $(n=213)$ and processed into plasma. The plasma levels of VCAM-1, ICAM-1 and E-Selectin concentrations of SCD patients and controls were measured using a double sandwich ELISA technique. Demographic information was also collected from the study subjects. Results: Levels of all soluble proteins (ICAM-1, VCAM-1 and E-Selectin) were significantly higher in HbSS steady-state patients compared to non-SCD controls $(p<0.001)$. Generally, SCD patients with complications had relatively higher levels of the soluble proteins compared to those in the steady-state. Of the SCD patients with complications, those with vaso-occlusion crisis (HbSS VOC) had relatively higher levels of ICAM-1, VCAM-1 and E-Selectin at $(62.42 \mathrm{ng} / \mathrm{mL} \pm 26.09),(634.99 \mathrm{ng} / \mathrm{mL} \pm 324.31)$ and $(236.77 \mathrm{ng} / \mathrm{mL}$ $\pm 114.40)$ respectively; Conclusion: Although levels of adhesion molecules were high in all the SCD patients with complications, those with vaso-occlusive crisis had higher levels. This might reflect an ongoing endothelial dysfunction in these patients. SCD patients with vaso-occlusive crisis presents with a more severe pathophysiology condition.
\end{abstract}

Keywords: sickle cell disease; endothelial dysfunction; soluble adhesion molecules; ICAM-1; VCAM-1 and E-Selectin 


\section{Introduction}

Sickle Cell Disease (SCD) refers to a number of genetic disorders associated with structurally abnormal haemoglobin, resulting in the episodic formation of sickle-shaped red blood cells and several clinical manifestations. The underlying genetic abnormality is a point mutation (GTG for GAG) in the gene for $\beta$-globin on chromosome 11, leading to the replacement of a glutamic acid residue with valine on the surface of the protein (termed $\mathrm{HbS}$ ) [1]. The SCD is one of the most common monogenetic disorders in the world, affecting nearly 1 in 600 African Americans [2], and an estimated 1 to $4 \%$ of babies born in sub-Saharan Africa [3]. The predominant genotypes that give rise to SCD include $\mathrm{Hb}$ $\mathrm{SS}, \mathrm{Hb} \mathrm{SC}, \mathrm{Hb} \mathrm{S} \beta^{+}$-thalassemia and $\mathrm{Hb} \mathrm{S} \beta^{0}$-thalassemia; other rare forms include hemoglobin SD and hemoglobin SE [4]. Complications from sickle cell disease can include gallstones, lung crises (acute chest syndrome), pulmonary hypertension, stroke, leg ulcers that do not heal, and eye damage [5]. The most common and frequently reported complications of SCD is renal dysfunction [6].

Endothelial dysfunction is associated specifically with anticoagulant properties, increased platelet aggregation, increased expression of vascular adhesion molecules (VCAM-1, ICAM-1 and E-Selectin), increased expression of chemokines and cytokines as well as increased reactive oxygen species production from the endothelium [7]. An important characteristic of endothelial dysfunction is the inability of arteries and arterioles to optimally dilate in response to an appropriate stimulus by vasodilators acting on the endothelium [8]. Soluble endothelial cell adhesion molecules (ICAM-1, VCAM-1 and E-Selectin) play a very important physiological role in the recruitment and binding of inflammatory cells to vascular endothelium, particularly in venules [9]. These potential markers of endothelial dysfunction are characterized by endothelial activation [10], and may play an important role in the development of SCD complications including VOC, leg ulcers and priapism [11]. E-Selectin induce specific inflammatory cells to slowly move across the surface of the endothelial, until a strong adhesive interaction develop on VCAM-1 as well as ICAM-1 to specific counter-ligands on the surface of inflammatory cells [9].

Levels of soluble VCAM-1 (sVCAM-1) have been shown to rise in the plasma of SCD patients. SCD patients have increased expression of adhesion molecules such as VCAM-1, ICAM-1 and E-Selectin during VOC and asymptomatic periods. Thus, a reflection of ongoing endothelial activation and damage is useful [12]. In Ghana, studies have been done in the area of epidemiology of SCD and its complications [13], but there is no report on the possible association between endothelial cell adhesion molecules (VCAM-1, ICAM-1 and E-Selectin) and endothelial dysfunction in SCD patients. Investigating the levels of these adhesion molecules in SCD patients with a hemolytic clinical sub-phenotype that includes priapism and leg ulcers may help in the management of SCD, as they may serve as potential biomarkers in these patients. The present study was aimed at determining plasma levels of ICAM-1, VCAM-1 and E-Selectin as markers of endothelial dysfunction in SCD patients in steady state, complications and controls.

\section{Methods}

\subsection{Study Site, Design and Sampling}

This was a cross-sectional study conducted at the Canter for Clinical Genetics (sickle cell clinic) of the Korle-Bu Teaching hospital (KBTH), Accra, Ghana from February 2013 to May 2015. The population of Ghana is about 25 million [14], and the prevalence of Sickle Cell Disease is 1.9\% of all births per year [15]. The out-patient morbidity reports compiled by the Ghana Health Service in 2002 and 2003 ranked SCD at the 37th and 36th positions, respectively [16]. KBTH is the largest hospital in Ghana with a bed capacity of about 2000 and 17 clinical and diagnostic departments including a Sickle Cell Clinic [17]. The hospital has an average daily attendance of 1500 patients and about 250 patient admissions [17]. Based on 95\% confidence level and 5\% allowable error, 213 SCD patients were randomly sampled at the Sickle Cell Clinic of KBTH including a control group of $60 \mathrm{HbAA}$ recruited from the National Blood Transfusion Centre located at KBTH. Patients with conditions such 
as diabetes mellitus, hypertension, coronary artery disease, renal failure, pregnancy and recent blood transfusion (three months prior to the study) were excluded from the study. The study protocol was approved by the Ethical and Protocol review Committee of University of Ghana Medical School. Written informed consents were obtained from participants/study subjects before samples were obtained. The determination of haemoglobin genotypes of the study participants was based on haemoglobin electrophoresis. Five milliliters $(5 \mathrm{mls})$ of venous blood sample was collected from each of the study participants into ethylene diamine tetracetic acid (EDTA) tubes for analysis. Vaso-occlusive crisis was clinically defined as pains in the bones, muscles and joints that are not due to any other cause and requiring parenteral analgesia and thus, admitted in the Centre for some hours. Steady state was defined clinically, as a patient who has been well and has not been in any crisis for at least two weeks. Leg ulcer was defined as a defect in the skin below the level of the knee and above the foot, which persists for six weeks or more. Priapism was also defined as a purposeless, persistent penile erection, particularly unaccompanied by any stimulation or sexual desire, which usually last for more than $6 \mathrm{~h}$.

\subsection{Laboratory Analysis}

Aliquot of $2.5 \mathrm{mls}$ of the blood sample was processed into plasma and stored at $-80{ }^{\circ} \mathrm{C}$. The plasma levels of VCAM-1, ICAM-1 and E-Selectin concentrations of HbSS SCD patients and controls were measured by using human VCAM-1, ICAM-1 and E-Selectin ELISA kits respectively (GenWay, San Diego, CA, USA, ELISA Development kit) according to the manufacturer's instructions.

Standard human VCAM-1 solutions of concentrations 10,000 pg/mL, $5000 \mathrm{pg} / \mathrm{mL}, 2500 \mathrm{pg} / \mathrm{mL}$, $1250 \mathrm{pg} / \mathrm{mL}, 625 \mathrm{pg} / \mathrm{mL}, 313 \mathrm{pg} / \mathrm{mL}$ and $156 \mathrm{pg} / \mathrm{mL}$ were prepared from the $10 \mathrm{ng}$ stock using the sample diluent buffer provided. Aliquots of $0.1 \mathrm{~mL}$ of each standard were added to the 96-well pre-coated plate in duplicate and $0.1 \mathrm{~mL}$ of the sample diluent buffer into the control well. A volume of $0.1 \mathrm{~mL}$ of the sample plasma (diluted 1:100 with sample diluent buffer) was added into the remaining wells in duplicate. The plate was sealed with cellophane and incubated at $37^{\circ} \mathrm{C}$ for $90 \mathrm{~min}$. After the incubation period, the plate content was discarded and the plate blotted with a paper towel.

Aliquots of $0.1 \mathrm{~mL}$ biotinylated anti-human ICAM-1 antibody working solution were added into each well and the plate incubated at $37^{\circ} \mathrm{C}$ for $60 \mathrm{~min}$. The plate was then washed 3 times with $0.01 \mathrm{M}$ phosphate buffered saline (PBS) using an automated plate washer. The washing buffer was then discarded and the plate blotted dry on paper towels. A volume of $0.1 \mathrm{~mL}$ of prepared Avidin-Biotin-Peroxidase Complex (ABC) working solution was added into each well and the plate incubated at $37^{\circ} \mathrm{C}$ for $30 \mathrm{~min}$. The plate was then washed 5 times with $0.01 \mathrm{M}$ PBS and blotted onto paper towels. After this, $90 \mu \mathrm{L}$ of prepared TMB color developing agent was added into each well and the plate incubated at $37^{\circ} \mathrm{C}$ in the dark for $25 \mathrm{~min} .0 .1 \mathrm{~mL}$ of prepared TMB stop solution was then added into each well. The optical density absorbance was then read at $450 \mathrm{~nm}$ in a microplate reader (Amersham Bioscience Limited, Buckinghamshire, UK).

For assay of E-Selectin, the procedure was repeated using Standard human E-Selectin solutions of concentrations 10,000 pg/mL, $8000 \mathrm{pg} / \mathrm{mL}, 4000 \mathrm{pg} / \mathrm{mL}, 2000 \mathrm{pg} / \mathrm{mL}, 1000 \mathrm{pg} / \mathrm{mL}, 500 \mathrm{pg} / \mathrm{mL}$, $250 \mathrm{pg} / \mathrm{mL}$ and $125 \mathrm{pg} / \mathrm{mL}$ and $0.1 \mathrm{~mL}$ biotinylated anti-human E-Selectin antibody working solution.

\subsection{Data Analysis}

The data was entered in to SPSS version-20 software. Frequency tables were generated for nominal and ordinal variables. The results were expressed as mean plus or minus standard deviation (mean \pm SD). The Kruskal Wallis test was used to compare differences in mean values among SCD patients in steady state and VOC, as well as those with leg ulcer and priapism with the healthy controls. Dunn's test was done as a post hoc analysis for multiple comparisons. Statistical significance was considered at $p<0.05$. 


\section{Results}

\subsection{Demographic and Clinical Features of the Study Participants}

The 213 enrolled subjects recruited in this study included $60 \mathrm{HbAA}$ apparently healthy controls (30 males, 30 females), and 153 SCD patients (83 males, 70 females). The mean age of the HbAA controls was $31.9 \pm 10.0$ years and $30.5 \pm 9.7$ years for the SCD group. Thirty percent SCD patients were in steady state $(n=46), 49 \%$ were in active VOC $(n=75), 14 \%(n=21)$ had an active leg ulcer, and $7 \%(n=11)$ had an active priapism. Males had twice as many leg Ulcers $(n=14)$ than females $(n=7)$ in symptomatic patients. However, females $(n=45)$ comprised of the majority of VOC (45 vs. 30 males) patients.

\subsection{Plasma ICAM-1, VCAM-1 and E-Selectin Levels in Controls and SCD Patients with and Without Complications}

Soluble protein levels in all SCD group and non-SCD controls are shown in Table 1. Levels of all soluble proteins (ICAM-1, VCAM-1 and E-Selectin) were significantly higher in HbSS steady-state patients compared to non-SCD controls $(p<0.001)$. The levels were further increased in HbSS VOC patients. There was no increase in all protein levels in leg ulcer HbSS compared to steady-state HbSS patients. There was increase in ICAM-1 level in HbSS priapism patients compared to HbSS steady-state patients $(p<0.001)$. Compared to HbSS leg ulcers, subjects with HbSS priapism had significantly higher ICAM levels $(p<0.001)$.

Table 1. Plasma ICAM-1, VCAM-1 and E-Selectin levels in controls and SCD patients with and without complications.

\begin{tabular}{|c|c|c|c|c|c|c|c|}
\hline Parameter & $\begin{array}{l}\text { HbAA Control } \\
\quad(n=60)\end{array}$ & $\begin{array}{l}\text { HbSS Steady State } \\
\qquad(n=46)\end{array}$ & $\begin{array}{c}\text { HbSS VOC } \\
(n=57)\end{array}$ & $\begin{array}{c}\text { HbSC VOC } \\
(n=18)\end{array}$ & $\begin{array}{l}\text { HbSS leg ulcer } \\
\quad(n=21)\end{array}$ & $\begin{array}{l}\text { HbSS Priapism } \\
\quad(n=11)\end{array}$ & $p$-Value \\
\hline ICAM-1 (ng/mL) & $\begin{array}{c}29.60 \\
(12.03-40.32)\end{array}$ & $\begin{array}{c}48.09 \\
(24.72-70.14)\end{array}$ & $\begin{array}{c}62.42 \\
(26.09-62.42)\end{array}$ & $\begin{array}{c}31.67 \\
(13.56-68.94)\end{array}$ & $\begin{array}{c}45.00 \\
(17.42-95.06)\end{array}$ & $\begin{array}{c}61.13 \\
(34.46-81.18)\end{array}$ & $<0.001$ \\
\hline VCAM-1 (ng/mL) & $\begin{array}{c}286.10 \\
(179.36-356.21)\end{array}$ & $\begin{array}{c}490.10 \\
(314.45-980.15)\end{array}$ & $\begin{array}{c}634.99 \\
(324.31-934.69)\end{array}$ & $\begin{array}{c}540.32 \\
(258.73-876.37)\end{array}$ & $\begin{array}{c}430.74 \\
(143.48-739.75)\end{array}$ & $\begin{array}{c}455.56 \\
(374.24-852.49)\end{array}$ & $<0.001$ \\
\hline E-selectin (ng/mL) & $\begin{array}{c}157.49 \\
(138.96-543.53)\end{array}$ & $\begin{array}{c}227.87 \\
(119.68-624.46)\end{array}$ & $\begin{array}{c}236.77 \\
(114.40-632.50)\end{array}$ & $\begin{array}{c}219.44 \\
(92.51-829.49)\end{array}$ & $\begin{array}{c}228.94 \\
(94.83-721.96)\end{array}$ & $\begin{array}{c}193.12 \\
(70.24-562.18)\end{array}$ & $<0.001$ \\
\hline
\end{tabular}

\section{Discussion}

This study highlights the involvement of adhesion molecules (VCAM-1, ICAM-1, and E-Selectin) in the endothelial dysfunction of SCD patients with and without complications. The detection of relatively higher plasma levels of VCAM-1, ICAM-1, and E-Selectin in SCD patients suggest that, adhesion molecules play a vital physiological role in the recruitment and binding of inflammatory cells to vascular endothelium [9]. Thus, it is not surprising that the levels of VCAM-1, ICAM-1, and E-Selectin recorded were even higher in SCD patients with VOC. In line with another study [12], increased VCAM-1, ICAM-1, and E-Selectin were seen in SCD patients during the vaso-occlusive state. Report from previous studies conducted elsewhere suggests that, SCD involves an abnormally activated, pro-adhesive endothelial cell state and demonstrate increased expression of the adhesion molecules [18-20]. The present study highlights a similar trend in levels of adhesion molecules (VCAM-1, ICAM-1, and E-Selectin) among patients with SCD. Higher levels of VCAM-1, ICAM-1, and E-Selectin in SCD patients are usually coupled with significantly low plasma NO levels, derived from the stimulating action of various biological modifiers such as hypoxia, thrombin, and cytokines on the normally quiescent endothelium [19], as well as from the pro-inflammatory effects of reperfusion-injury physiology [21,22]. Thus, higher levels of VCAM-1, ICAM-1, and E-Selectin are expected in SCD associated complications due to a possible activation of inflammatory cells in these patients, as observed in the present study.

Impaired NO production, which leads to decreased bioavailability of NO due to higher levels of these adhesion molecules could result in endothelial dysfunction $[23,24]$. This partly explains the higher levels of adhesion molecules observed in all the SCD patients recruited. Besides, a possible 
association between plasma levels of VCAM-1, ICAM-1, and E-Selectin, and endothelial dysfunction, exists in SCD patients. In line with other similar studies [18,20], soluble levels of the adhesion molecules were lower in the controls. The observed increase in VCAM-1 and ICAM-1 levels in SCD patients probably reflects an increased level of endothelial cell adhesion molecule expression and activation in these patients as well as an increased capacity for the adhesion of sickle erythrocytes and leukocytes to the endothelium [20]. The view of SCD as a state of abnormal endothelial activation could present a potential opportunity for novel therapeutic approaches in that pharmacologic inhibition of endothelial cell activation might be clinically beneficial. This is because VCAM-1, ICAM-1, and E-Selectin are all markers of endothelial dysfunction, and have been implicated in the pathology of SCD [25,26]. Higher levels of E-Selectins demonstrated in the plasma of patients with SCD in both steady state and during VOC agree with the work of Najjar et al. [27] in patients of Saudi Arabia ethnicity and non-Saudi patients.

Increased levels of soluble (s) VCAM-1 and sICAM-1 have been reported to be associated with increased haemolytic rate in patients with SCD [28,29]. The similar levels of soluble endothelial adhesion molecules observed in both HbSS patients in steady state and those with leg ulcer could partly be due to a similar degree of hemolysis in these patients. Sub-phenotypes of SCD including priapism and leg ulcers are associated with increased hemolysis [30,31], a decrease in the NO precursor, L-arginine [32,33], reduced NO bioavailability [34], and a disruption of the coagulation cascade [35]. Therefore, a combination of each of these processes may play a significant role in the upregulation of adhesion molecule expression [35]. Nevertheless, soluble ICAM-1, VCAM-1 and E-Selectin may serve as promising biomarkers of pain in VOC, owing to the continuous increase in levels of all endothelial adhesion molecules in the current study. Higher levels of ICAM-1, VCAM-1 and E-Selectin might be very useful in predicting patients at high risk of endothelial dysfunction [10], especially in the case of SCD patients with VOC, in this study.

Our study had some limitations. We could not gather information on bilirubin, liver function tests, LDH, reticulocyte count, the percentage of patients on hydroxyurea and other environmental factors such as smoking and BMI, which may as well affect endothelial function.

\section{Conclusions}

Elevated levels of VCAM-1, ICAM-1 and E-Selectin were generally found in SCD patients, as compared to the control group in the present study. Elevated levels of soluble ICAM-1, VCAM-1 and E-Selectin found in Ghanaian HbSS patients in steady-state may reflect universal endothelial injury in SCD patients. Increased levels of ICAM-1, VCAM-1 and E-Selectin in HbSS VOC demonstrated further increase of endothelial injury associated with this complication. HbSS leg ulcer and priapism were not associated with further increase of endothelial injury in SCD patients.

Acknowledgments: The authors are thankful to the office of research, innovation and development (ORID), University of Ghana and University of Ghana-Carnegie Next Generation of Academics in Africa Project for funding this research. The authors are also grateful to the staff and patients of the Centre for Clinical Genetics (Sickle Cell Clinic) who took part in the study. Also, the authors would like to thank the volunteers who donated blood and consented to take part in the study as control subjects.

Author Contributions: C.A.-B. conceived the idea, designed the experiments and analyzed the data; E.S.D. drafted the first manuscript; F.S. recruited the patients and collected data; B.D. supervised the collection of data and revised the draft manuscript; G.B.D. collected data and analyzed major part of the Laboratory; K.H.O. entered data and drafted the manuscript alongside ESD; A.D. reviewed the first manuscript by ESD; C.A.D. analyzed and interpretated the data collected; E.I. supervised the clinical characterization and ensured quality of the laboratory. All authors read and approved the final version of the manuscript.

Conflicts of Interest: The author declare no conflict of interests.

Ethics Approval and Consent to Participate: Ethical approval was obtained from the Ethical and Protocol Review Committee University of Ghana Medical School, College of Health Sciences. All subjects gave a written consent before participating in the study. 


\section{References}

1. Stuart, M.J.; Nigel, R.L. Sickle-cell disease. Lancet 2004, 364, 1343-1360. [CrossRef]

2. Gladwin, M.T.; Vichinsky, E. Pulmonary complications of sickle cell disease. N. Engl. J. Med. 2008, 359, 2254-2265. [CrossRef] [PubMed]

3. Aliyu, Z.Y.; Gordeuk, V.; Sachdev, V.; Babadoko, A.; Mamman, A.I.; Akpanpe, P.; Attah, E.; Suleiman, Y.; Aliyu, N.; Yusuf, J.; et al. Prevalence and risk factors for pulmonary artery systolic hypertension among sickle cell disease patients in Nigeria. Am. J. Hematol. 2008, 83, 485-490. [CrossRef] [PubMed]

4. Saraf, S.L.; Molokie, R.E.; Nouraie, M.; Sable, C.A.; Luchtman-Jones, L.; Ensing, G.J.; Campbell, A.D.; Rana, S.R.; Niu, X.M.; Machado, R.F.; et al. Differences in the clinical and genotypic presentation of sickle cell disease around the world. Paediatr. Respir. Rev. 2014, 15, 4-12. [CrossRef] [PubMed]

5. National Institute of Health. Sickle Cell Disease: Symptoms, Diagnosis, Treatment and Recent Developments. Winter 2011, 5, 18.

6. Tsaras, G.; Owusu-Ansah, A.; Boateng, F.; Amoateng-Adjepong, Y. Complications associated with sickle cell trait: A brief narrative review. Am. J. Med. 2009, 122, 507-512. [CrossRef] [PubMed]

7. Al-Isa, A.N.; Thalib, L.; Akanji, A.O. Circulating markers of inflammation and endothelial dysfunction in Arab adolescent subjects: Reference ranges and association with age, gender, body mass and insulin sensitivity. Atherosclerosis 2010, 208, 543-549. [CrossRef] [PubMed]

8. Gopi, K.K.; Shyamal, C.B.; Christopher, G.K. Endothelial Dysfunction and Diabetes: Effects on Angiogenesis, Vascular Remodeling, and Wound Healing. Int. J. Vasc. Med. 2012, 2012, 918267.

9. Alon, R.; Feigelson, S. From rolling to arrest on blood vessels: Leukocyte tap dancing on endothelial integrin ligands and chemokines at sub-second contacts. Semin. Immunol. 2002, 14, 93-104. [CrossRef] [PubMed]

10. Kato, G.J.; Martyr, S.; Blackwelder, W.C.; Nichols, J.S.; Coles, W.A.; Hunter, L.A.; Brennan, M.L.; Hazen, S.L.; Gladwin, M.T. Levels of soluble endothelium-derived adhesion molecules in patients with sickle cell disease are associated with pulmonary hypertension, organ dysfunction, and mortality. Br. J. Haematol. 2005, 130, 943-953. [CrossRef] [PubMed]

11. Antwi-Boasiako, C.; Frimpong, E.; Ababio, K.G.; Bartholomew, D.; Campbell, D.A.; Gyan, B.; Antwi, A.D. The Role of Nitric Oxide in Vaso-occlusive Crisis in Sickle Cell Disease Patients in Ghana. Donnish J. Med. Med. Sci. 2015, 2, 52-55.

12. Kuryliszyn, A.; Moskal, P.; Klimiuk, A.; Sierakowski, S. Soluble adhesion molecules (sVCAM-1, sE-Selectin), vascular endothelial growth factor (VEGF) and endothelin-1 in patients with systemic sclerosis: Relationship to organ systemic involvement. Clin. Rheumatol. 2005, 24, 111-116. [CrossRef] [PubMed]

13. Ama, K.; Edwin, F.E.; Victor, E. Controlling sickle cell disease in Ghana-ethics and options. Pan Afr. Med. J. 2011, 10, 14.

14. Ghana Demographics Profile 2013. Index Mundi. 2013. Available online: http:/ /www.indexmundi.com/ ghana/demographics_profile.html (accessed on 23 June 2016).

15. Ohene-Frempong, K.; Oduro, J.; Tetteh, H.; Nkrumah, F. Screening newborns for sickle cell disease in Ghana. Pediatrics 2008, 121, S120. [CrossRef]

16. Antwi-Boasiako, C.; Frimpong, E.; Ababio, G.K.; Dzudzor, B.; Ekem, I.; Gyan, B.; Sodzi-Tettey, N.A.; Antwi, D.A. Sickle Cell Disease: Reappraisal of the role of Foetal Haemoglobin Levels in the frequency of Vaso-Occlusive crisis. Ghana Med. J. 2015, 49, 102-106. [CrossRef] [PubMed]

17. Annual Report of the Korle-Bu Teaching Hospital, 2012. Korle-Bu Teaching Hospital: Accra, Ghana, 2013. Available online: https://www.kbth.gov.gh/assets/downloads/pdf/Korlebu-Annual-Report-2013.pdf (accessed on 23 June 2016).

18. Duits, A.J.; Pieters, R.C.; Saleh, A.W.; Van Rosmalen, E.; Katerberg, H.; Berend, K.; Rojer, R.A. Enhanced levels of soluble VCAM-1 in sickle cell patients and their specific increment during vasoocclusive crisis. Clin. Immunol. Immunopathol. 1996, 81, 86-98. [CrossRef]

19. Alex, A.S.; Anna, N.S.; Jeanne, H.; Robert, P.H. Modulation of endothelial cell activation in sickle cell disease: A pilot study. Blood 2001, 97, 1937-1941.

20. Conran, N.; Fattori, A.; Saad, S.T.O.; Costa, F.F. Increased Levels of Soluble ICAM-1 in the Plasma of Sickle Cell Patients Are Reversed by Hydroxyurea. Am. J. Hematol. 2004, 76, 343-347. [CrossRef] [PubMed]

21. Kaul, D.K.; Hebbel, R.P. Hypoxia/reoxygenation causes inflammatory response in transgenic sickle mice but not in normal mice. J. Clin. Investig. 2000, 106, 411-420. [CrossRef] [PubMed] 
22. Osarogiagbon, R.R.; Choong, S.; Belcher, J.D.; Vercellotti, G.M.; Paller, M.S.; Hebbel, R.P. Reperfusion injury pathophysiology in sickle transgenic mice. Blood 2000, 96, 314-320. [PubMed]

23. Witting, P.K.; Rayner, B.S.; Wu, B.J.; Ellis, N.A.; Stocker, R. Hydrogen peroxide promotes endothelial dysfunction by stimulating multiple sources of superoxide anion radical production and decreasing nitric oxide bioavailability. Cell. Physiol. Biochem. 2007, 20, 255-268. [CrossRef] [PubMed]

24. Kaneto, H.; Katakami, N.; Matsuhisa, M.; Matsuoka, T.A. Role of reactive oxygen species in the progression of type 2 diabetes and atherosclerosis. Mediat. Inflamm. 2010, 2010, 453892. [CrossRef] [PubMed]

25. Belcher, J.D.; Mahaseth, H.; Welch, E.T.; Otterbein, E.L.; Hebbel, P.R.; Vercellotti, G.M. Haemoxygenase-1 is a modulator of inflammation and vaso-occlusion in transgenic sickle mice. J. Clin. Investig. 2006, 116, 808-816. [CrossRef] [PubMed]

26. Aslan, M.; Freeman, A.B. Redox-Dependent Impairment of Vascular Function in Sickle Cell Disease. Free Radic. Biol. Med. 2007, 43, 1469-1483. [CrossRef] [PubMed]

27. Najjar, S.A.; Adam, S.; Ahmed, A.; Qari, M. Markers of endothelial dysfunction and leucocyte activation in Saudi and non-Saudi haplotypes of sickle cell disease. Ann. Hematol. 2017, 96, 141-146. [CrossRef] [PubMed]

28. Nath, K.A.; Shah, V.; Haggard, J.J.; Croatt, A.J.; Smith, L.A.; Hebbel, R.P.; Katusic, Z.S. Mechanisms of vascular instability in a transgenic mouse model of sickle cell disease. Am. J. Physiol. Regul. Integr. Comp. Physiol. 2000, 279, 1949-1955. [CrossRef] [PubMed]

29. Gladwin, M.T.; Schechter, A.N.; Ognibene, F.P.; Coles, W.A.; Reiter, C.D.; Schenke, W.H.; Csako, G.; Waclawiw, M.A.; Panza, J.A.; Cannon, R.O. Divergent nitric oxide bioavailability in men and women with sickle cell disease. Circulation 2003, 107, 271-278. [CrossRef] [PubMed]

30. Rother, R.P.; Bell, L.; Hillmen, P.; Gladwin, M.T. The clinical sequelae of intravascular hemolysis and extracellular plasma hemoglobin: A novel mechanism of human disease. JAMA 2005, 293, 1653-1662. [CrossRef] [PubMed]

31. Hsu, L.L.; Champion, H.C.; Campbell-Lee, S.A.; Bivalacqua, T.J.; Manci, E.A.; Diwan, B.A.; Schimel, D.M.; Cochard, A.E.; Wang, X.; Schechter, A.N.; et al. Hemolysis in sickle cell mice causes pulmonary hypertension due to global impairment in nitric oxide bioavailability. Blood 2007, 109, 3088-3098. [CrossRef] [PubMed]

32. Morris, C.R.; Kato, G.J.; Poljakovic, M.; Wang, X.; Blackwelder, W.C.; Sachdev, V.; Gladwin, M.T. Dysregulated arginine metabolism, hemolysis-associated pulmonary hypertension, and mortality in sickle cell disease. JAMA 2005, 294, 81-90. [CrossRef] [PubMed]

33. Ataga, K.I.; Moore, C.G.; Jones, S.; Olajide, O.; Strayhorn, D.; Hinderliter, A.; Orringer, E.P. Pulmonary hypertension in patients with sickle cell disease: A longitudinal study. Br. J. Haematol. 2006, 134, 109-115. [CrossRef] [PubMed]

34. Reiter, C.D.; Wang, X.; Tanus-Santos, J.E.; Hogg, N.; Cannon III, R.O.; Schechter, A.N.; Gladwin, M.T. Cell-free hemoglobin limits nitric oxide bioavailability in sickle-cell disease. Nat. Med. 2002, 8, 1383-1389. [CrossRef] [PubMed]

35. Klings, S.E.; Bland, A.D.; Rosenman, D.; Princeton, S.; Odhiambo, A.; Li, G.; Bernard, A.S.; Steinberg, M.H.; Farber, W.H. Pulmonary arterial hypertension and left-sided heart disease in sickle cell disease: Clinical characteristics and association with soluble adhesion molecule expression. Am. J. Hematol. 2008, 83, 547-553. [CrossRef] [PubMed]

(C) 2018 by the authors. Licensee MDPI, Basel, Switzerland. This article is an open access article distributed under the terms and conditions of the Creative Commons Attribution (CC BY) license (http://creativecommons.org/licenses/by/4.0/). 